\title{
ATRX Gene Mutation Negative
}

National Cancer Institute

\section{Source}

National Cancer Institute. ATRX Gene Mutation Negative. NCI Thesaurus. Code C160321.

A genetic finding indicating that AT RX gene mutations have not been detected in a sample. 